\title{
Két évtized sikerstratégiája: a belga rendészeti reform elözményei és megvalósulása ${ }^{1}$
}

\section{BUDAVÁRI Árpád ${ }^{2}$}

Bár a döntés már 1998-ban megszületett róla, idén 20 éve, 2001. január 1-jén indult útjára a belgiumi rendészeti reform. A társadalmat megrázó, súlyos büncselekmények kudarcos kezelése miatt legitimációs válságba sodródó rendőrség néhány év alatt visszanyerte a közösség bizalmát. A közösségorientált rendészeti filozófián alapuló egységes nemzeti rendőrség nem csupán a rendészettudomány nemzetközi és hazai múvelőinek általános elismerését vívta ki, hanem iránytüként szolgált az ezredforduló Európájának több rendörségi átalakulása - így a holland, a skót, a svéd vagy az északír rendőrség reformja - számára. Tanulmányom első részében a belga rendészeti törvény, a témában született értékelések, a tudományos szakirodalom, valamint - különösen a jelenlegi helyzet bemutatása során - a belga rendőrség múködéséröl született újságcikkek feldolgozásával részletesen elemeztem a belga rendészeti reform előzményeit, a reform utáni belga rendörség felépítését, valamint müködése ellenörzésének rendszerét. A második részben a változásoknak a rendészet pluralizálódását érintő vonatkozásait, valamint a belga rendőrség és a belga rendészeti rendszer értékelését ismertetem a reform első tíz évét követően és napjainkban. Az elemzés során fókuszba helyezem a rendészeti reformokat életre hivó okokat, az egységes nemzeti rendőrség demokratikus müködésének biztosítását szolgáló intézkedéseket, a helyi és nemzeti biztonsági érdekek érvényesülését és az ezredforduló rendészeti reformjainak jelenlegi helyzetét. Mindezekből következtetéseket kívánok levonni arra, hogy az ezredforduló idején született rendőrségi reform miként müködik a mai biztonsági problémák kezelése során.

Kulcsszavak: rendörségi reform, plurális rendészet, centralizáció, belga rendörség, közösségorientált rendészet, absztrakt rendészet

\footnotetext{
A tanulmány az Innovációs és Technológiai Minisztérium Kooperatív doktori program doktori hallgatói ösztöndíj programjának a Nemzeti kutatási, fejlesztési és innovációs alapból finanszírozott szakmai támogatásával készült. 2 Budavári Árpád r. ezredes, a Fejér Megyei Rendőr-főkapitányság Gárdonyi Rendőrkapitányság vezetője, rendőrségi főtanácsos; Nemzeti Közszolgálati Egyetem Rendészettudományi Doktori Iskola, doktori hallgató.

Árpád Budavári r. Colonel, Head of the Gárdonyi Police Headquarters of the Fejér County Police Headquarters, Chief Police Advisor, University of Public Service, Doctoral School of Law Enforcement, PhD student. E-mail: budavaria@ fejer.police.hu
} 


\section{A reform elözményei}

A belga önkormányzatiság és ezzel együtt az önkormányzati rendőrség történelme Belgium 1830-as függetlensége előtti időkre nyúlik vissza. Az önkormányzatokat a francia megszállók hozták létre 1795-ben, vagyis a települések hamarabb (1800ban) függetlenné váltak, mint maga az állam. A 2776 helyi önkormányzat múködésének észszerűsítésére csupán 1977-ben került sor, amikor 589 önkormányzatba vonták össze ôket. A flamand régiónak 308, Brüsszel fôvváros régiójának 19, a vallon régiónak pedig 262 önkormányzata maradt. Minden önkormányzatnak volt rendőre. Az 1998-as reform előtt 255 vidéki kistelepülésen múködött rendőrség, 935 rendőrt alkalmazva. Ez az önkormányzati rendőrség létszámának alig 5\%-át tette ki, míg a városi rendőrségeken szolgáló rendőrök létszáma 17810 volt. Az elaprózott településszerkezetben a polgármesterek által irányított és az önkormányzatok által finanszírozott önkormányzati rendőrségek folyamatos forráshiánnyal küzdöttek. Munkájukat elsősorban a közterület rendjének fenntartására koncentrálták, és bár törvényi felhatalmazással rendelkeztek a bűnügyi igazságszolgáltatási funkció ellátására is, a valóságban csupán 88 önkormányzati rendőrség alkalmazott bünügyi

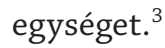

Belgium nemzeti rendvédelmi testülete a csendőrség volt, amely létét az ország francia megszállásától eredezteti. A későbbi holland megszállás (1815-1830) idején a testület Maréchaussée néven múködött tovább. Múködésének jogi alapjait 1957-ben fektették le a csendőrségrôl szóló törvény megalkotásával. 1992-ben demilitarizálták; ez a változtatás a későbbi, teljes rendőrséget érintő reform előzményének tekinthető. A csendőrség alapvetően országos rendvédelmi szervezet volt, amely a közrend fenntartásáért felelt. Múködésének öt szintje volt a nemzetitôl a néhány önkormányzat területén múködő egységekig. Az 1957-es csendőrségi törvényig nyomozó hatásköre nem volt. Az 1998-as reformot megelőzően a csendőrség belső átszervezésének eredményeképpen a korábbi öt szervezeti szint háromra csökkent, a szervezet piramisszerkezete alacsonyabbá vált, bürokratizmusa enyhült. ${ }^{4}$

A bủnügyi igazságszolgáltatási funkció sokáig háttérbe szorult a rendfenntartással szemben mind az önkormányzati rendőrségekben, mind pedig a csendőrségnél. Önálló bűnüldöző szervezet létrehozására 1919-ben került sor. Az igazságügyi rendőrség az ügyészségnek alárendelt országos szervezet volt, amely létszámában (körülbelül 1500 fő) messze elmaradt „nagytestvéreitől”, az önkormányzati rendőrségtől és a csendőrségtől. Szervezetében a központi irányító szervezeten kívül 27 területi szervezeti egység múködött, amelyek illetékessége a bíróságokéhoz igazodott.

\footnotetext{
3 Elke Devroe - Paul Ponsaers: Reforming the Belgian Police System between Central and Local. In N. R. Fyfe - J. Terpstra - P. Tops (szerk.): Centralizing Forces? Comparative Perspectives on Contemporary Police Reform in Northern and Western Europe. The Hague, Boom Legal Publishers - Eleven, 2013. 78.

4 Devroe-Ponsaers (2013): i. m. 80.
} 
A három szervezet egymástól teljesen függetlenül múködött, nem volt köztük funkcionális vagy földrajzi munkamegosztás. Ez óhatatlanul rivalizálást okozott. ${ }^{5}$

$\mathrm{Az}$ önkormányzati rendőrség és a csendőrség viszonyában egyfajta spontán egyensúly alakult ki a 20. század második felében. Ott, ahol a tehetősebb önkormányzatok erősebb rendőrséget tudtak múködtetni, a csendőrség kevesebb erővel volt jelen. Erőforrásait azokra a területekre súlypontozta, ahol arra az önkormányzati rendőrség szerényebb lehetőségei miatt inkább szükség volt. Emiatt a csendőrség Vallóniában sokkal markánsabban volt jelen, mint a tehetősebb flamand településeken. A spontán munkamegosztás más módon is megvalósult. Az önkormányzati rendészetek legtöbbje - átvéve az önkormányzati hivatalok múködésének kultúráját - hivatalnokszervezetként múködött. Este és hétvégén területét „átengedte” a csendőrségnek, amely a hatásköri átfedések miatt gyakorlatilag hivatali időn kívül átvette az önkormányzati rendőrség szerepét. A csendőrség előbb említett átszervezését követően a kevésbé hierarchikus szervezet nagyobb figyelmet tudott fordítani a helyi problémákra, ez azonban további rivalizálást eredményezett az önkormányzati rendészet és a csendőrség között. ${ }^{6}$

A rivalizáló kapcsolat a csendőrség és az igazságügyi rendőrség között is fennállt, különösen azt követően, hogy az 1957-es csendőrségi törvény nyomozó hatósági hatáskörrel is felruházta az addig leginkább a közterületek rendjét őrző szervezetet. A rivalizálást szemléletesen példázza a különböző rendőri szervezetek adatbázisainak helyzete. Mind a csendőrség, mind az igazságügyi rendőrség külön központi adatbázissal rendelkezett, és egymással versengve próbálták ezek használatára megnyerni az ország 589 önkormányzatát. A települések 25\%-a a csendőrség, 25\%-a pedig az igazságügyi rendőrség adatbázisához csatlakozott, a maradék 50\% egyáltalán nem rögzítette adatait semmilyen központi adatbázisban. Emiatt gyakorlatilag mindkét szervezet rendkívül hiányos adatbázisokkal volt kénytelen operálni.7

Az 1990-es évek közepétől több törekvés is született a hatáskörükben, feladatrendszerükben sok esetben átfedést mutató, egymással rivalizáló szervezetek múködésének összehangolására. 1994-ben a kormány koordinációs szervezetet hozott létre, amelynek feladata a szervezetek közötti együttmúködés javítása volt. 1994-ben királyi rendelet született az úgynevezett „minimális biztonsági előírásokról". Ez fektette le azokat a kritériumokat, amelyek alapján az egyes települések esetében meghatározhatóvá vált a rendőri erők minimális létszáma. Ugyanebben az évben Átfogó önkormányzati rendészet címmel rendészeti stratégiát bocsátottak ki, amely a településeken megvalósítandó rendészeti célokat határozta meg. Szintén királyi rendelet szabályozta, hogy az önkormányzatoknak önállóan vagy egymással együttmúködve 24 órás rendőrséget kell településeiken múködtetni, amihez az állam többletforrást biztosított. 1995-ben a kormány úgynevezett rendőrségközi zónák létrehozásával kísérelte meg a rendőri szervezetek közötti feladatmegosztás 
összehangolását. A zónák területi határán belül a három szervezet, önállóságát megőrizve, konzorciumként múködött együtt. Az önkormányzati rendőrségek részvétele ebben önkéntes volt, belépésüket az állam többlettámogatással ösztönözte. A zónák értékelése során a kormány már deklarálta, hogy az intézkedéssel a rendőri rendszer fokozatos átszervezését kívánta elősegíteni. ${ }^{8}$

A reformhoz vezető okok nem csupán a rendőrség szervezeteinek múködési zavaraiban keresendők. A belga önkormányzati igazgatásban a települések széles mérlegelési jogkörrel rendelkeztek a közbiztonság helyi problémáinak kezeléséhez, a szövetségi törvények adta keretek helyi viszonyokra adaptálásában nagy mozgásterük volt. A szövetségi alkotmány 1988-as módosítását követően a közigazgatás háromszintűvé - nemzeti, regionális, helyi - vált. A közbiztonságot érintően elsősorban a nemzeti és a helyi szintnek volt feladata, a szociálpolitika, az oktatás, a foglalkoztatás, az egészségügy, a kultúra, a lakhatás és a területrendezés hatáskörei elsősorban a regionális kormányokhoz lettek telepítve. Ez a feladatmegosztás idővel feszültséget teremtett a szövetségi és regionális kormányok között, hiszen a bűnözés társadalmi okait regionális szinten kezelték, míg a közbiztonságért a nemzeti kormányok és a polgármesterek feleltek. ${ }^{9}$

$\mathrm{Az}$ önkormányzat a nemzeti és a regionális szintű szabályozás csomópontjának tekinthető. A regionális hatóságok irányítják az életminőséggel kapcsolatos szociálpolitikai feladatok végrehajtását, a szövetségi hatóságok feladatai pedig a bűnüldözésre és a közrend fenntartására irányulnak, miközben az önkormányzatok mindkét szabályozási dimenzió helyi vonatkozásaiban érintettek. A feszültségek azonban nem csupán az igazgatás vertikális tagozódásában jelentkeztek. Flandriában a flamand kormánytól az önkormányzatoknak szánt külön finanszírozás jelentős volt, Vallóniában azonban a bűnmegelőzés költségeit főként szövetségi forrásokból fedezték, mivel a régiók ehhez nem tudtak hozzájárulni. ${ }^{10}$

A közbiztonságot érintően további bizonytalansági tényező volt, hogy az 1988-as államreform (New Communal Act, 1988) a bünözés lehetséges okaival foglalkozó szakpolitikák költségvetéseit regionális szintre telepítette. A rendőrség felügyelete továbbra is nemzeti (szövetségi) szinten maradt, azonban a rendőri erők háromszintű szerveződése (szövetségi, regionális, helyi) túl széttagolt és diffúz volt a szövetségi szintű kezeléshez. ${ }^{11} \mathrm{Az}$ irányítás fentiekben felsorolt diszfunkciói miatt az önkormányzati rendőrségek és a szövetségi szinten szerveződő csendőrség egymással konkuráló szervezetekké váltak. ${ }^{12}$ A belga rendőrség 1998-as reformját megelőzően már több fontos változást és modernizációs intézkedést bevezetett munkájának hatékonyabbá tétele és a megrendült bizalom helyreállítása végett. Minden

8 O. Anciaux - K. Muylle - Paul Ponsaers: Federaal rapport vijfhoeksoverleg - Jaar 1997 - De IPZ's in de schoot van het vijfhoeksoverleg. In Algemene Politiesteundienst, Afdeling Politiebeleidsondersteuning, Kluwer Editorial, 1998. 34.

Elke Devroe: Purple Vests. The Origins of Plural Policing in Belgium. European Journal of Policing Studies, 2. (2015), 3. 309.

10 Devroe (2015): i. m. 308.

1 Devroe (2015): i. m. 308.

12 Devroe-Ponsaers (2013): i. m. 80. 
változtatási törekvésnek szembesülnie kellett a széttagolt három különböző rendőri erôt magában foglaló struktúrával, amely egyszerre volt gátja az együttmúködésnek, az információáramlásnak és a rendészet egységes jövőképalkotásának. ${ }^{13}$

A felsorolt általános problémákon túl, a reformokat indukáló társadalmi elégedetlenség kiváltó okai között három, búnözéssel összefüggő jelenséget lehet megemlíteni. ${ }^{14}$ Az első, az 1980-as évek bünözési hulláma, amelynek során először az 1982 és 1985 között „Nivelles bandája” néven elhíresült bű́nszervezet múködése okozott komoly társadalmi feszültséget. A banda országszerte hajtott végre, nem egyszer halálos áldozatokat követelő fegyveres rablásokat szupermarketekben. Ugyanebben az időszakban több, terrorszervezetek által bankok ellen intézett támadás is jelentősen növelte a búnözéstől való félelmet. A legnagyobb, nemzetközi visszhangot kiváltó esemény a Heysel-stadionban rendezett BEK-döntő során a futballhuligánok okozta pánikjelenségben meghalt 34 ember tragédiája volt.

A rendőrség fentebb már említett belső feszültségei a nemzetközi szervezett bűnözés elleni küzdelmet is jelentősen megnehezítették, ennek káros következményeivel a berlini fal 1989-es leomlása után szembesült a belga társadalom. Az országba jelentős számú különböző származású migráns települt, a bizonytalanság és a félelem érzését keltve. Brüsszel lett a migránsok zavargásainak központja. A veszélyesnek ítélt városokból a lakosság vidékre költözött. A társadalmi feszültségek a politikai szélsőségek irányába tolták el a közhangulatot, 1991 novemberében a Vlaams Blok nevủ szélsőjobboldali párt nyerte a választásokat.

A harmadik nagy visszhangot kiváltó és a rendőrség múködésének elégtelenségére rávilágító eseménysorozat az úgynevezett Marc Dutroux-ügy volt. A pedofil Dutroux az 1980-as években hat kislányt rabolt el, közülük négyet megölt. 1996-os letartóztatását az áldozatok melletti szolidaritási akciók kísérték. A „Fehér léggömb menet" alkalmával 300 ezer ember vonult ki Brüsszel utcáira, demonstrációjuk a rendőrség és az igazságszolgáltatás alkalmatlansága elleni kinyilatkoztatás is volt. Dutroux két év múlva egy átkísérés során megszökött, elfogása sem a rendőrségnek, hanem egy fegyvertelen erdőőrnek volt köszönhető. Az eset következtében a belga rendőrségbe vetett intézményi bizalom gyakorlatilag megszűnt. A reform nem tủrt további halasztást.

\section{A rendőrség megreformálása: centralizáció (?), integrálás, konzultáció, autonómia}

Még ebben az évben - tehát 1998-ban - a minden érintettet megszólító úgynevezett Octopus konzultáción egyhangúan fogadták el a kétszintű, integrált rendőrségi

\footnotetext{
13 Willy Bruggeman - Elke Devroe - Marlen Easton: Evaluatie van 10 jaar politiehervorming: Terugkijken in het verleden en vooruitkijken in de toekomst. Antwerpen-Apeldoorn, Maklu, 2010. 21.

14 Devroe (2015): i. m. 308-309.
} 
szervezetről, azaz a belga rendőrség átszervezéséről szóló törvényt (WGP-törvény), ${ }^{15}$ amely a három különálló rendőri szolgálatot egy egységes, két szinten (szövetségi és helyi) működő rendőri szervezetbe integrálta. A szövetségi szinten 2001. január 1-jétől, helyi szinten pedig egy évvel később hatályba lépő törvény új alapokra helyezte a rendőrség szervezetét, megalapozta a közösségorientált rendészeti stratégia egységes alkalmazását, átalakította a rendőrség együttmüködési filozófiáját. ${ }^{16}$

A WGP-törvény legfontosabb céljai az alábbiak voltak: ${ }^{17}$

- a rendőrség szervezeti egységei és a rendőri múködés helyi és szövetségi szintje közötti együttműködés javítása;

- a rendőrség és a közigazgatási, igazságügyi hatóságok közötti kapcsolat javítása;

- az információkezelés fejlesztése;

- a rendőri szolgáltatások színvonalának egységesítése;

- a közösségi rendészeti szemlélet kialakítása;

- a bűnügyi szolgálat hatékonyságának javítása;

- erős helyi rendőrségek.

Az egységes belga nemzeti rendőrség két szervezési szintje helyi és szövetségi keretek között jött létre. A szervezeti szintek önállók, kapcsolatuk funkcionális. A helyi rendőrség feladata, hogy helyi szinten biztosítsa az alapvető rendőri szolgáltatások ellátását. A törvény a minimális rendőri szolgáltatásokat az egész állam területén egységesen garantálja (WGP-törvény 3. cikk).

$\mathrm{Az}$ integrált nemzeti rendőrség létszáma a reformot követően 47 ezer fő lett, amelyből 39 ezer fő hivatásos rendőr. ${ }^{18}$ A helyi rendőrség 196 zónába szerveződött, amelyek közül 118 a flamand, 72 a vallon és 6 a brüsszeli közigazgatási régióban létesült. Közülük 50 zóna egyetlen önkormányzat területén müködik. A zónákban szolgáló rendőrök száma rendkívül eltérő, a reformot követően a legkisebb 50, a legnagyobb 2800 rendőrt foglalkoztatott. ${ }^{19}$

A reform nemcsak a struktúrát, hanem a tartalmat is érintette. Ehhez kellő alapot nyújtott az a reform idejére nemzetközi kitekintésben is elfogadottá vált kritika, amely a 20. század döntő részében alkalmazott rendőrségi modelleket - a bünözés elleni harc és a rendfenntartás modelljét - elégtelennek ítélte meg arra, hogy azt a 21. század rendőrségein is alkalmazzák. A kritikákat Verhage és Ponsaers az alábbi négy pontban foglalta össze: ${ }^{20}$

\footnotetext{
Wet tot organisatie van een geïntegreerde politiedienst, gestructureerd op twee niveaus 7. December 1998.

Bruggeman-Devroe-Easton (2010): i. m. 12.

Bruggeman-Devroe-Easton (2010): i. m. 13.

Bruggeman-Devroe-Easton (2010): i. m. 12.

Bruggeman-Devroe-Easton (2010): i. m. 13.

Antoinette Verhage - Paul Ponsaers: Impacts of Community Oriented Policing. In Gerben Bruinsma - David Weisburd (szerk.): Encyclopedia of Criminology and Criminal Justice (ECCJ). New York, Springer, 2013. 2430-2435.
} 
„1. A rendőri kapacitás nagymértékủ növelése nem hatékony stratégia a búnözés és a rendezetlenségek kezelésére. A mennyiségi fejlesztés nem oldja meg a »hogyan csináljunk jó rendészetet« kérdés minőségi problémáit.

2. A lakosság a rendőrség "szeme és füle«, mely nélkül a rendőrség nem tudja megakadályozni a bűncselekményeket. A rendőrségnek külső orientációval kell rendelkeznie, és ki kell szolgálnia a polgárokat.

3. A hagyományos rendőri modellek klasszikus taktikája túl reaktív, mivel nem befolyásolja a búnözés és a rendbontás lehetséges okait.

4. A rendőri stratégiákat ugyanolyan módon alkalmazzák a különböző problémákra (»ugyanaz a sablon mindenkinek megfelel«); több »személyre szabott válaszra" van szükség."

A WGP-törvény végrehajtásáról szóló 2001-es királyi rendelet egyértelmüsítette és hat funkcióban nevezte meg az egységes, minimális rendőrségi szolgáltatásokat. Ezek a szomszédsági rendőrség, az ügyfélszolgálat, a reagáló szolgálat, az áldozatvédelem, a bűncselekményekkel kapcsolatban a helyi rendőrség által folytatott nyomozás, valamint a közrend fenntartása voltak. A hat funkció a 2008-2011-es Nemzeti Biztonsági Terv ajánlása alapján 2009-ben egészült ki a közlekedésrendészet helyi feladataival. ${ }^{21} \mathrm{~A}$ kormány 2003-ban fogadta el Belgium egységes rendészeti stratégiáját, amely a közösségorientált rendészeti stratégiára épült.

A finanszírozás a szövetségi rendőrséget érintően országosan, míg a helyi rendőrség vonatkozásában döntő részben helyi szinten valósul meg. Ezt vizsgálva Boels és munkatársai rámutattak, hogy amíg a helyi rendőrség müködtetése 2005-ben a költségvetés 77,7\%-át tette ki, addig ez az arány 2008-ra már csak 72,2\% volt, a reform első tíz éve után megfigyelhető tehát a központi adminisztráció bizonyos fokú megerősödése. ${ }^{22}$

A rendőri szervezetek helyi és szövetségi szinten is jelentős autonómiával rendelkeznek, az integrált közösségi rendfenntartást azonban egymással kooperálva kell biztosítaniuk. A rendőrségi igazgatás két szintje között nem keletkezett hierarchikus viszony, a szövetségi és helyi rendőrségi erők funkcionális kapcsolatban állnak. A törvény szerint alapvetően a helyi rendőrség biztosítja a helyi szintű közösségi rendfenntartást, azonban a szövetségi rendőrség feladatai között is szerepel a helyi rendőrség támogatása a helyben jelentkező rendőri feladatok ellátásában, és a helyi rendőrség néhány feladatát is meg kell valósítania a településeken. ${ }^{23}$

A belga nemzeti rendészeti stratégia végrehajtásának időszakos feladatait a négyéves ciklusokra készülő Nemzeti Biztonsági Terv (Nationaal Veiligheidsplan) határozza meg, amely szövetségi és helyi szintre vonatkozóan is tartalmaz kötelező

\footnotetext{
21 Lásd: www.ejustice.just.fgov.be/cgi_loi/change_lg.pl?language=nl\&la=N\&cn=2001091731\&table_name=wet

22 Dominique Boels - Paul Ponsaers - Antoinette Verhage: Capaciteit bij de Belgische politie: meer blauw op straat? In Handboek Politiediensten. Afl. 99, 423, 2011. 1-40. 3.

23 WGP-törvény 3. cikk.
} 
elveket. Ezeket a szintén négyévente készülő helyi biztonsági tervekbe is be kell építeni.

\subsection{Helyi rendörségek}

A helyi rendőrség operatív irányítását a rendőrkapitány végzi. A rendőrkapitány felel a helyi rendészeti stratégia és a biztonsági terv feladatainak végrehajtásáért. Minden, a helyi rendőrséget és annak feladatait érintő kérdésben tájékoztatja a polgármestert vagy a rendőrségi tanácsot. E feladatát érintően havonta kell tájékoztatnia a polgármestert vagy a rendőrségi tanácsot a rendőrség működéséről és a rendőrség müködését érintő panaszokról is. ${ }^{24}$

A helyi rendőrségek (a WGP szóhasználatában rendőrségi zónák vagy övezetek) irányításában az önkormányzatok a reformot követően is jelentős hatáskörökkel rendelkeznek. A 196 rendőrségi zóna közül azokat, amelyek illetékességi területén több település található, a települések polgármestereiből, valamint az önkormányzatok által delegált tagokból álló rendőrségi tanács irányítja. A WGP-törvény 47. cikkének értelmében az önkormányzat vagy a rendőrségi tanács a korábban már hivatkozott, királyi rendeletben meghatározott minimumszabályoknak megfelelően meghatározza a helyi rendőrségek személyi összetételét, költségvetésének elosztását, a rendőrség személyzeti politikáját. Amennyiben a helyi rendőrségek erőforrásai nem elégségesek, a polgármesterek és a rendőrségi tanácsok katasztrófa, tömeges zavargások vagy a közrendet súlyosan fenyegető helyzetben kérhetik a szövetségi rendőrség segítségét. ${ }^{25} \mathrm{~A}$ közbiztonság helyi feladatainak képviseletében a polgármester befolyást gyakorolhat a polgármesterek tanácsadó testületén keresztül is. A Polgármesterek Tanácsának (Raad van Burgemeesters) feladata a belügyminiszter által kidolgozott szabályozási aktusok véleményezése. A tanács tagjait és helyetteseiket a király nevezi ki hároméves, megújítható időtartamra. A tanácsok tagokat delegálnak a Szövetségi Rendőrségi Tanácsba. ${ }^{26}$

A Helyi Rendőrség Állandó Bizottságának felállításáról (Vaste Commissie van de Lokale Politie) egy 2006. december 7-én hatályba lépő királyi rendelet (az állandó bizottságról szóló rendelet) döntött. ${ }^{27}$ A bizottság tagja a helyi rendőrségek 18 rendőrkapitánya (kilenc flamand, hét vallon és két brüsszeli), a különböző megfigyelői vagy szakértői státusszal rendelkező tagok, a bel- és igazságügyi minisztériumok delegáltjai, valamint a Polgármesterek Tanácsának elnöke. A bizottság 18 rendőrkapitány tagját a rendőrkapitányok kollégiuma választja meg. ${ }^{28} \mathrm{~A}$ kéthavonta ülésező bizottság a minisztériumok felkérésére vagy saját kezdeményezésére

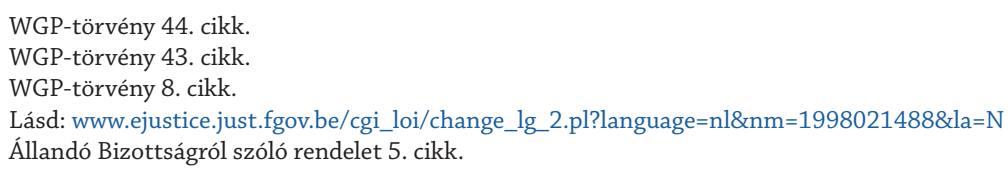


foglal állást a helyi rendőrségeket érintő kérdésekben, amelyeket részletesen sem a WGP-törvény, sem az állandó bizottságról szóló rendelet nem nevesít. A bizottság munkájával a helyi rendőrségek egységes működését felügyeli és képviseli azokat a Szövetségi Biztonsági Tanácsban.

A helyi (a WGP-törvény szóhasználata szerint zóna- vagy övezeti) biztonsági terv tartalmazza a polgármesterek és az ügyész által meghatározott, a nemzeti és globális célokkal összhangban álló biztonsági prioritásokat, a rendőrség ezekhez illesztett felépítését, létszámát és költségvetését, valamint azt, hogy a helyi rendőrség miként járul hozzá a szövetségi rendőri feladatok ellátásához. ${ }^{29}$

A rendőrség közigazgatási és igazságügyi feladatainak összehangolására minden rendőri körzetben Övezeti Biztonsági Tanács (Zonale Veiligheidsraad) múködik, amelynek vezetője a polgármester (több települést magában foglaló zóna esetében a rendőrségi tanács vezetője), az ügyész, a rendőrkapitány és a szövetségi rendőrség koordinátora. Az övezeti tanács feladata a helyi biztonsági terv előkészítése is. ${ }^{30}$

A WGP-törvény egységes végrehajtására kiadott 2001. szeptember 17-i királyi rendelet 3. cikke alapján a helyi rendőrségek funkciói az alábbiak szerint alakultak: ${ }^{31}$

- Az első a közösségi munka és a közösségek támogatása. Ezt a funkciót a közösségorientált rendfenntartás sarokkövének tekintik, ez teremti meg a kapcsolatot a rendőrség és az állampolgárok között. Ez a kapcsolat teszi lehetővé, hogy a rendőrök tudomást szerezzenek a lakosság problémáiról, és ahol lehet, megoldásokat kínáljanak. Ezenkívül a közösséggel való kapcsolat révén a rendőrök informálhatják a lakosságot és a helyi közösségeket, valamint végrehajthatják azokat a feladatokat, amelyek személyes kapcsolattartást igényelnek. A közösségben működő rendőrség fel tudja mérni a helyben jelentkező kisebb konfliktusokat, és segítséget tud nyújtani a felszámolásukban. Alapvetően öt feladat tartozik ehhez a funkcióhoz:

- gyalogos vagy kerékpáros járőrözés;

- látható jelenlét a közterületeken;

- kapcsolattartás a polgárokkal és a közösségekkel;

- a polgárok és közösségek tájékoztatása;

- szolgáltatások a polgárok számára.

- A második alapvető rendőri feladat az elérhetőség a polgárok számára. A helyi rendőrségnek a nap 24 órájában elérhetőnek kell lennie telefonon vagy a rendőrség épületében diszpécserszolgáltatással. Fontos szempont az is, hogy a rendőrség könnyen megtalálható és elérhető legyen a városközpontok közelében.

\footnotetext{
WGP-törvény 36. cikk.

WGP-törvény 35. cikk.

Nicky Rogge - Marijn Verschiede: A Composite Index of Citizen Satisfaction with Local Police Services. HogeschoolUniversiteit Brussel Research Papers 2012/13 (2012. február) 4-6. - idézi Sallai János et al.: A jó állam - jó rendészet speciális jelentés kiindulási alapjai. Magyar Rendészet, 18. (2018), 2. 181-189.
} 
- A harmadik rendőri funkció a beavatkozás, amely a rendőrök által a beavatkozások során nyújtott szolgáltatásokat foglalja magában. E funkció sikeres teljesítése érdekében a rendőri egységeknek gyorsan és szakszerűen kell reagálniuk minden, a helyszínen rendőri segítséget kérő hívásra. Szükségük van arra is, hogy időt és erőforrásokat fordítsanak a probléma megértésére és feldolgozására. Az etikai kódex tartalmazza azokat az irányelveket, amelyek a rendőrnek az intézkedések során tanúsított viselkedésével kapcsolatban irányadók. E kódex kimondja, hogy a rendőröknek különös figyelmet kell fordítani a törvény előtti egyenlőség elvére, az udvarias és tisztelettudó magatartásra is.

- A negyedik alapvető funkció az áldozatvédelem, amely magában foglalja a bűncselekmények vagy balesetek áldozatainak tájékoztatását, a segélyezésükkel kapcsolatos ügyintézést és gondozásukat is. A belga igazságszolgáltatás rendszerében az áldozatvédelmi támogatások ügyintézése a helyi rendőrség feladata. A súlyos esetekben az áldozatok a helyi rendőrség speciálisan felkészített szakemberére támaszkodhatnak.

- Az ötödik funkció a helyi hatáskörben lefolytatott nyomozásoké.

- A hatodik pedig az őrködő jelenlét megszervezése és végrehajtása a közbiztonság és közlekedésbiztonság védelmezésére.

Mindehhez a 2008-2011-es Nemzeti Biztonsági Terv egy hetedik funkciót, a közlekedésrendészeti feladatokat is javasolta, ez jelenleg már része a rendőrség funkcióinak.

\subsection{A szövetségi rendörség}

A szövetségi rendőrség élén a rendőrség főbiztosa áll. A főigazgató végzi a főigazgatóságok közötti koordinációt, biztosítja a műveletekhez szükséges támogatást. Felelős a szövetségi rendőrség mindennapi múködéséért, garantálja a szövetségi rendőrség feladatainak integrált végrehajtását. A közigazgatási és igazságügyi rendészeti feladatok ellátását önálló feladat- és hatáskörrel irányítják a szakterületek főigazgatói, munkájuk operatív irányítását a főigazgató végzi, felügyeletét a funkcióknak megfelelően a közigazgatási főigazgatót érintően a belügyminiszter, az igazságügyi rendészeti főigazgatót érintően az igazságügy-miniszter látja el. ${ }^{32}$ A két szakmai főigazgató mellett a funkcionális feladatok irányítását a támogatási és irányítási főigazgató végzi. A főigazgatóságok irányítása alatt a szövetségi rendőrségi feladatokat a decentralizált koordinációs és támogatási igazgatóságok, a decentralizált igazságügyi igazgatóságok (mindegyikből 27 van), valamint a kommunikációs és információs központok látják el. ${ }^{33}$ 
A rendőrség operatív működését irányító döntéshozó testület a Szövetségi Rendőrség Irányító Bizottsága (Directiecomité, a továbbiakban Irányító Bizottság). A bizottság elnöke a szövetségi rendőrség főbiztosa, tagjai a közigazgatási, az igazságügyi, valamint az erőforrás-gazdálkodási és információs főigazgató. Az Irányító Bizottság dönt az alkalmazandó rendőrségi stratégiáról, javaslatot készít a Nemzeti Biztonsági Tervről, az integrált biztonságról szóló keretmegállapodásról, a rendőrség személyzeti, logisztikai, pénzügyi és információs stratégiájáról. Döntéseit alapvetően konszenzussal hozza, ennek hiányában a főbiztos dönt. A főbiztos feladata a miniszterek tájékoztatása is a miniszteri hatáskörbe tartozó kérdésekben. ${ }^{34}$

A szövetségi rendőrség legfőbb koordinációs és irányító testülete a Szövetségi Rendőrségi Tanács (Federaale Politieraad, a továbbiakban: Tanács). Elnökét a király négy évre nevezi ki a bel- és igazságügy-miniszterek javaslatára. A Tanács tagjai a szövetségi föügyész és további ügyészek, a régiók kormányzói, a bíróságok képviselője, a három közigazgatási régió egy-egy polgármestere, a rendőrség főbiztosa és a helyi rendőrségek állandó bizottsága vezetője. ${ }^{35}$

A Tanács alapvető feladata, hogy a szövetségi és a helyi rendőrségek parancsnokának jelentései alapján elvégezze a rendőrség működésének és szervezetének átfogó értékelését, foglaljon állást a Nemzeti Biztonsági Terv tervezetéről, értékelje annak végrehajtását. A Tanács állásfoglalásának kikérése kötelező minden olyan jogszabály előkészítése során, amely a helyi vagy a szövetségi rendőrség számára új feladatot határoz meg.

A szövetségi rendőrség által elkészített négyéves Nemzeti Biztonsági Terv tartalmazza a szövetségi rendőrségnek a bel- és igazságügy-miniszterek által meghatározott kiemelt célkitűzéseit, azok elérésének módját, valamint az ehhez rendelt emberi és anyagi erőforrások megosztását. A 2000-ben elkészült első Nemzeti Biztonsági Tervet követően 2004-ig kellett várni arra, hogy a szövetségi parlament elfogadja az integrált biztonság keretszabályozását, amely összehangolja a Nemzeti Biztonsági Tervet, a bűnmegelőzési, a büntető- és a büntetési politikát. ${ }^{36}$

A rendőrség belső működésének, valamint a helyi és szövetségi szintek együttműködésének összehangolásáért az Integrált Rendőrségi Koordinációs Bizottság (Coördinatiecomité van de Geïntegreerde Politie opgericht) felel. A bizottság a szövetségi rendőrség végrehajtó bizottságának tagjaiból és a Helyi Rendőrségek Állandó Bizottságának tisztségviselőiből áll. A bizottságot felváltva vezeti a szövetségi rendőrség főbiztosa és a Helyi Rendőrségek Állandó Bizottságának elnöke. A bizottság belső ügyrendjében meghatározottak szerint munkáját a felsoroltakon kívül más rendőrségi szakemberek is segíthetik. A Koordinációs Bizottság feladata, hogy a belés igazságügy-miniszterek kérésére vagy saját kezdeményezésre dolgozzon ki ajánlásokat az integrált rendőrség múködési stratégiáját érintő fontosabb személyzeti,

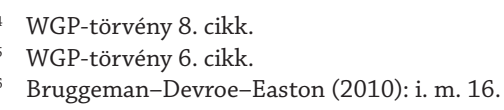


logisztikai, költségvetési és informatikai kérdésekben. A hatáskörébe tartozó kérdésekben a bizottság egyeztet a Polgármesterek Tanácsaival is. ${ }^{37}$

A szövetségi rendőrség és az igazságszolgáltatás hatóságai között is működik egy konzultációs fórum, ezt Justipol Konzultációs Platformnak (overlegplatform Justipol, rövidítve Justipol) nevezik. Tagjai a Főügyészek Testületének tagjai, a szövetségi ügyvédek delegáltja, az Ügyészi Tanács Elnöke, a szövetségi rendőrség végrehajtó bizottságának delegáltjai és a helyi rendőrségek delegáltjai. A Justipol feladata a rendőrség és az igazságszolgáltatás közötti együttmúködés elősegítése. Munkája során ajánlásokat fogalmaz meg a bel- és igazságügy-miniszterek hatáskörébe tartozó, a bűnügyi igazságszolgáltatást érintő kérdésekben. ${ }^{38}$

A törvény rendelkezik az integrált rendőrség információs és adatkezelési stratégiájáért felelős bizottság létrehozásáról is (Comité Informatie en ICT). ${ }^{39}$

\subsection{A rendörség múködésének irányítása és ellenörzése $e^{40}$}

A rendőrség irányítását az igazságügy-miniszter és a belügyminiszter egymással szoros együttműködésben, együttesen gyakorolják. A két miniszter együttesen felelős a rendőri erők általános politikájáért és koordinációjáért. ${ }^{41} \mathrm{~A}$ rendőrséget közigazgatási hatósági feladatainak ellátásában a belügyminiszter, míg a bűnügyi igazságszolgáltatási feladatainak teljesítése körében az igazságügy-miniszter irányítja. ${ }^{42}$

Az igazságügy-miniszter a Főügyészek Tanácsának (Raad van Procureurs-generaal) véleménye alapján iránymutatásokat ad ki a kriminálpolitikáról, és a belügyminiszterrel együtt koordinálja az általános rendészeti stratégia végrehajtását. Ez a kettős hatáskör arra is alkalmas, hogy az igazságügy-miniszter az integrált megközelítés elveit érvényesítve gondoskodjon arról, hogy az ügyészségre vonatkozó irányelvek beépüljenek a Nemzeti Biztonsági Tervbe. A 2008-2011-es Nemzeti Biztonsági Terv deklarálja, hogy az ügyészség és a rendőrség közötti együttmúködést folyamatosan javítani kell, ennek érdekében a szövetségi és helyi szinten múködő konzultációs testületeket is arra ösztönzi, hogy az azok munkájában részt vevő rendőrségi és ügyészségi delegáltak az addiginál szorosabban működjenek együtt. ${ }^{43}$ Annak érdekében, hogy a Nemzeti Biztonsági Terv alapvető céljai beépüljenek a rendőrségi zónák biztonsági terveibe, a két miniszter körlevelet bocsátott ki, amelyben egységesítette a zónák biztonsági terveinek felépítését, szempontrendszerét. ${ }^{44}$

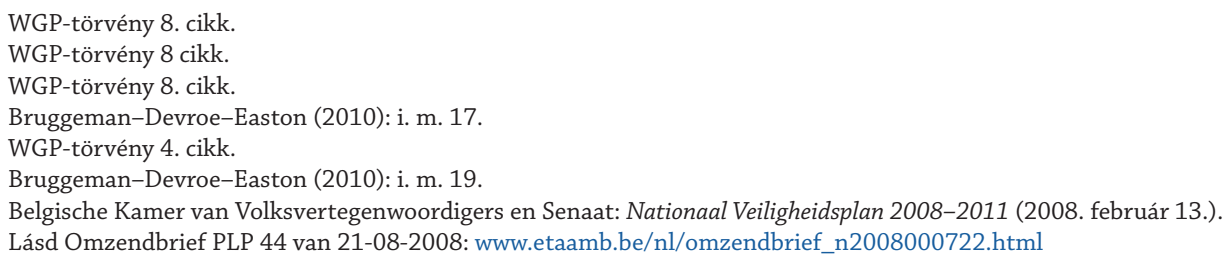


A fentieken kívül a belügyminiszter és a kormányzó a polgármester vagy az önkormányzatok törvényes működéséért felelős felügyeleti jogkörében eljárva utasíthatja az önkormányzatokat az egész országra kiterjedő fenyegetettséggel kapcsolatos feladatok elvégzésére akkor is, ha az esemény csak egyetlen településen lokalizálódik, vagy ha a közérdek megköveteli a beavatkozásukat. ${ }^{45}$

A rendőri körzetek szervei által hozott döntések szövetségi felügyelete első fokon a kormányzó, másodfokon a belügyminiszter hatásköre.

A bűnügyi igazságszolgáltatás rendőrségi működésének ellenőrzésében kiemelt szerep jut az ügyésznek. Az ügyész felelős a nyomozásért. Múködési körzetében meghatározza azokat az ügyeket, amelyek nyomozását kiemelten kezelik. Az ügyészek a körzeti biztonsági tanácsok tagjai, és így részt vesznek a helyi rendőrség politikájának és stratégiájának meghatározásában, valamint az övezeti biztonsági tervek kidolgozásában. Közvetlen kapcsolatban állnak a körzetük szövetségi igazságügyi rendőrségének decentralizált egységével. Az igazságügyi nyomozási egyeztetések során biztosítják a koordinációt a helyi és a szövetségi rendőrség között az igazságügyi rendőrség feladatainak végrehajtása érdekében. Az igazságügyi hatóságok befolyást gyakorolhatnak a Szövetségi Rendőrségi Tanácsban és a Körzeti Biztonsági Tanácsban való jelenlétük révén is. ${ }^{46}$

$\mathrm{Az}$ egységes, átlátható és elszámoltatható mủködés ellenőrzése számos módon biztosított. A rendőrség ellenőrzésére jogosult intézmények a következők:

- a klasszikus parlamenti és kormányzati ellenőrző szervek;

- a Szövetségi és a Helyi Rendőrség Főfelügyelősége (Algemene Inspectie, rövidítve: AIG);

- az úgynevezett P Bizottság (Vast Comité van Toezicht op de Politiediensten, azaz a Rendőrségi Szolgálatok Felügyeletének Állandó Bizottsága), amely a Parlament felügyelete alatt áll, és felügyeli az összes rendőri erőt, valamint az AIG-t;

- a rendőri információkezelés felügyeleti szerve (Vlaamse Hoge Handhavingsraad Voor Ruimte en Milieu, rövidítve: VHRM);

- a belső ellenőrzési szolgálatok;

- a szövetségi ügyészség felügyelete.

Az egységes nemzeti rendőrség irányításában és ellenőrzési rendszerében a fékek és ellensúlyok széles bázisa alapozta meg az átláthatóságot és az elszámoltathatóságot. A leírtakból kitűnik, hogy annak érdekében, hogy a rendőrség irányításában és rendőrséget érintő döntésekben ne alakulhasson ki monopolhelyzet, valamint széles körben érvényesüljön a kollektív bölcsesség, a kormányzati szinten megvalósuló duális irányítás mellett számos tanácsadó és döntés-előkészítő konzultációs fórum müködik.

WGP-törvény 64. cikk.

46 Lásd: https://polis.osce.org/country-profiles/belgium 


\section{A reform karrierjének rövid összefoglalása}

Az új szervezet elfogadtatása nem volt zökkenőmentes. Komoly bírálatok érték az átalakítást amiatt, hogy annak hangsúlyai elsősorban a strukturális átalakításokra estek, a reform szervezeti kultúrára gyakorolt hatását nem vették figyelembe, emiatt annak a szervezeten belüli elfogadottsága sem volt egyértelmü. A korábbi területi és hierarchikus berendezkedésről az újra való átállás nem múködött zökkenőmentesen, ennek leginkább az információáramlás látta kárát. Öt év alatt azonban sikerült, hogy a korábbi területi határok a rendőrség belső viszonyrendszereiben is elmosódjanak, az erők eloszlása a rendőrség létszámemelésének következtében egyenletesebb lett. ${ }^{47}$

A szervezeti átalakításon túlmenően a belga kormánynak el kellett oszlatnia azokat a kétkedéseket is, amelyek a helyi biztonság kérdéseinek háttérbe szorulásától tartottak a nemzeti biztonsági kérdések prioritásba kezelésével. Az új rendszerben a rendészeti stratégia alapját a közösségi rendészet filozófiája jelentette, azonban ennek folyamatos működtetéséhez arra is szükség volt, hogy a belga kormány átértékelje az önkormányzatok és a magánrendészet szerepét a közbiztonság rendszerében, és a közbiztonság rendőrségen kívüli szereplőinek helyzetbe hozásával az úgynevezett MAS-törvény megalkotásával új lendületet adjon a rendészet pluralizálódásának. Mindezek után a reform első tíz évét követően a Szövetségi Rendőrségi Tanács (Federaale Politieraad) már egyértelmúen amellett foglalt állást, hogy a rendőrség átalakítása beváltotta a hozzá füzött reményeket.

Az évezred második évtizedében a belga politikai helyzet radikális változása, valamint a globális biztonsági problémák (migrációs folyamat erősödése, terrorizmus) markáns belgiumi megjelenése miatt a változó biztonsági környezetben a rendszer fenntartható múködése okozta és okozza a mai napig a legnagyobb problémát. A szövetségi politika jobbra tolódását követően a közösségi rendészet elvei a háttérbe szorultak, és a represszív, ellenőrzésekre építő kontrollszemlélet vált uralkodóvá. ${ }^{48}$ A rendészet regionális és helyi szintjein azonban jelentős számban maradtak a korábbi, kereszténydemokrata és szociáldemokrata vezetés képviselői és a rendészetben az általuk képviselt közösségi szemlélet. A helyi és regionális, valamint a szövetségi szinten alkalmazott rendészeti stratégia között éles törésvonal keletkezett. ${ }^{49}$ A represszív rendőrségi stratégia alkalmazását támasztották alá a 2016-ban Brüszszel repülőterén és metrójában történt, 35 ember életét követelő terrortámadások is. A rendőrség szemléletváltása azonban a társadalom közösségeitől való eltávolodással járt. A kritikák középpontjába az etnikai kisebbségek hátrányos megkülönböztetése és a rendőri brutalitás térnyerése került, amihez számos, országos felháborodást kiváltó rendőri intézkedés szolgáltatott alapot. Mindez odáig vezetett,

\footnotetext{
47 Devroe-Ponsaers (2013): i. m. 85.

48 Elke Devroe - Paul Ponsaers: The Power Context of Police Reform in Belgium - The Brussels Case: A Shift in the Style of Policing after the Terrorist Attacks. Policing: A Journal of Policy and Practice, 15. (2021), 1. 306.

49 Devroe-Ponsaers (2021): i. m. 309-310.
} 
hogy mára már senki sem beszél a 20 éve még európai példaként emlegetett rendőri reform sikeréről, sőt a BBC belga rendőrségről készült 2021. áprilisi beszámolójában új reformokat sürget. ${ }^{50}$

A belga rendőrség 20 éve történt átalakításának értékelése számos tanulságot hordoz magában mind a rendőrség és a társadalom 21. századi kapcsolatának megértéséhez, mind pedig a rendőrségi reformok tapasztalatainak hazai hasznosításához. Ezek részletes elemzéséhez e tanulmány keretei nem elégségesek. Újabb tanulmányomban tervezem bemutatni a belga rendőrségi reform másik ágát, az önkormányzati és a magánrendészetek szerepét a helyi biztonsági problémák kezelésében. Rendkívül tanulságosnak tartom, ezért részletesen elemzem a reformot ért kritikákat, az új rendőrségi szervezet társadalmi elfogadásának folyamatát, majd pedig azokat az eseményeket és körülményeket, amelyek a társadalom és a rendőrség eltávolodásához vezettek az évezred második évtizedében. A tanulmány összegzésében számba veszem a belga rendőrségi reform két évtizedre szóló sikerének, majd jelenlegi válságos helyzetének okait. Végül pedig a rendészeti reformokra vonatkozó, általános érvényű tanulságokat ismertetem az olvasóval.

\section{IRODALOMJEGYZÉK}

Anciaux, O. - K. Muylle - Paul Ponsaers: Federaal rapport vijfhoeksoverleg - Jaar 1997 - De IPZ's in de schoot van het vijfhoeksoverleg. In Algemene Politiesteundienst, Afdeling Politiebeleidsondersteuning. Kluwer Editorial, 1998. 34.

Belgische Kamer van Volksvertegenwoordigers en Senaat: Nationaal Veiligheidsplan 2008-2011 (2008. február 13.). Online: www.senate.be/www/?MItabObj=pdf\&MIcolOb$j=$ df\&MInamObj=pdfid\&MItypeObj=application/pdf\&MIvalObj=67109617

Boels, Dominique - Paul Ponsaers - Antoinette Verhage: Capaciteit Bij De Belgische Politie: Meer Blauw Op Kantoor? Handboek Politiediensten. Vol. 96. Mechelen: Kluwer, 2011. 1-40.

Beake, Nick: Belgian police 'are supposed to protect us'. BBC (2021. április 3.). Online: www.bbc. com/news/av/world-europe-56606747

Bruggeman, Willy - Elke Devroe - Marlen Easton: Evaluatie van 10 jaar politiehervorming: Terugkijken in het verleden en vooruitkijken in de toekomst. Antwerpen-Apeldoorn, Maklu, 2010. Online: https://biblio.ugent.be/publication/1066454/file/6743746

Devroe, Elke: Purple Vests. The Origins of Plural Policing in Belgium. European Journal of Policing Studies, 2. (2015), 3. 304-325.

Devroe, Elke - Paul Ponsaers: Reforming the Belgian Police System between Central and Local. In N. R. Fyfe - J. Terpstra - P. Tops (szerk.): Centralizing Forces? Comparative Perspectives on Contemporary Police Reform in Northern and Western Europe. The Hague, Boom Legal Publishers - Eleven, 2013. 77-98. Online: https://doi.org/10.13140/2.1.3519.4889

Devroe, Elke - Paul Ponsaers: The Power Context of Police Reform in Belgium - The Brussels Case: A Shift in the Style of Policing after the Terrorist Attacks. Policing: A Journal of Policy and Practice, 15. (2021), 1. 299-313. Online: https://doi.org/10.1093/police/pay038

Rogge, Nicky - Marijn Verschiede: A Composite Index of Citizen Satisfaction with Local Police Services. Hogeschool-Universiteit Brussel Research Papers 2012/13 (2012. február). Online: https://doi.org/10.1108/13639511311329697

50 Nick Beake: Belgian police 'are supposed to protect us'. BBC, 2021. április 3. 
Sallai János - Tihanyi Miklós - Vári Vince - Mátyás Szabolcs: A jó állam - jó rendészet speciális jelentés kiindulási alapjai. Magyar Rendészet, 18. (2018), 2. 181-189. Online: https://doi. org $/ 10.32577 / \mathrm{mr} .2018 .2 .13$

Verhage, Antoinette - Paul Ponsaers: Impacts of Community Oriented Policing. In Gerben Bruinsma - David Weisburd (szerk.): Encyclopedia of Criminology and Criminal Justice (ECCJ). New York, Springer, 2013. 2430-2435. Online: https://doi.org/10.1007/978-1-4614-5690-2

\section{ABSTRACT}

\section{A Two Decades of Success Strategy: Background and Implementation of the Belgian Police Reform}

Árpád BUDAVÁRI

Although the decision thereon was already made in 1998, the reform of law enforcement in Belgium began twenty years ago, on 1 January 2001. Police, drifting into a legitimacy crisis over the failure to deal with serious crimes that shake society, have regained the trust of the community in a matter of years. Based on a community-oriented policing philosophy, the unified national police force has not only earned the general recognition of international and domestic law enforcement practitioners, but also served as a compass for several police transformations in Europe, including Dutch, Scottish, Swedish and Northern Irish police reform. In the first part of my study, I analyse in detail the antecedents of the Belgian police reform, the structure and operation of the post-reform Belgian police and the system established for the control of its operation, by processing the Belgian law enforcement law, the evaluations on the subject, the scientific literature and, especially in the current situation, the newspaper articles. In the second part, I describe the implications of the changes for the pluralism of the police and the evaluation of the Belgian police and the Belgian police system after the first ten years of the reform and today. In my analysis, I focus on the reasons for policing reforms, the measures to ensure the democratic functioning of a unified national police force, the enforcement of local and national security interests, and the current state of law enforcement reforms carried out at the turn of the millennium. From all this, I try to draw conclusions about how the police reform of the turn of the millennium works in dealing with today's security problems.

Keywords: police reform, plural policing, centralisation, Belgian police, community-oriented policing, abstract policing 